\title{
Human Immunodeficiency Virus-1 Infection of Macrophages In Vitro Neither Induces Tumor Necrosis Factor (TNF)/Cachectin Gene Expression Nor Alters TNF/Cachectin Induction by Lipopolysaccharide
}

\author{
James R. Munis, Douglas D. Richman, and Richard S. Kornbluth \\ Departments of Medicine and Pathology, University of California, San Diego, and the Veterans Administration Medical Center, San \\ Diego, California 92161
}

\begin{abstract}
The synthesis of tumor necrosis factor (TNF)/cachectin was assessed in primary monocyte-derived macrophage (MDM) cultures after in vitro infection with a macrophage-tropic strain of HIV-1 (HTLV-III $\mathrm{Ba-L/85}$ ). Productive and cytopathic infections in MDM cultures were established using a high multiplicity of infection $(m .0 . i .=3)$ under conditions that minimized endotoxin contamination. Culture supernatants were tested for TNF/cachectin activity by $\mathbf{L 9 2 9}$ cell cytotoxicity assay, and TNF/cachectin mRNA was assessed by a sensitive PCR amplification technique that could detect between 1 and 10 cells fully activated for TNF/cachectin expression. Unstimulated MDM cultures produced no detectable levels of TNF/cachectin activity or mRNA, consistent with previous demonstrations that production of this cytokine by macrophages is an inducible and not a constitutive event. HIV-1 infection failed to induce detectable TNF/cachectin activity or mRNA in these unstimulated cultures. In addition, the responsiveness of macrophages to lipopolysaccharide (LPS) induction of TNF/cachectin production was assessed in dose-response and kinetic experiments. No differences between infected and uninfected cultures were discernable. These results demonstrate that productive and cytopathic infection with a macrophage-tropic strain of HIV-1 does not alter the regulation of TNF/cachectin expression in macrophages. (J. Clin. Invest. 1990. 85:591-596.) HIV - AIDS • macrophages • tumor necrosis factor • lipopolysaccharide $\cdot$ polymerase chain reaction
\end{abstract}

\section{Introduction}

Human immunodeficiency virus (HIV) is established as the etiologic agent of AIDS $(1,2)$; however, the pathogenic link between infection and disease remains largely undefined. With the discovery that cells of the monocyte/macrophage lineage serve as viral targets and viral reservoirs (3-9), speculation has arisen that the macrophage may play a role in the pathogenesis of AIDS through the dysregulation of one or several macrophage-derived cytokines, including tumor necrosis factor $(\mathrm{TNF})^{1} /$ cachectin $(10)$. This hypothesis follows from the ob-

Address reprint requests to Dr. Kornbluth, Infectious Diseases (V-111F), Veterans Administration Medical Center, 3350 La Jolla Village Drive, San Diego, CA 92161.

Received for publication 1 September 1989.

1. Abbreviations used in this paper: MDM, monocyte-derived macrophage; m.o.i., multiplicity of infection; PCR, polymerase chain reaction; TNF, tumor necrosis factor.

The Journal of Clinical Investigation, Inc.

Volume 85, February 1990, 591-596 servation that at least two viruses, influenza virus (11) and Sendai virus (12), induce macrophage TNF/cachectin production after in vitro infection. In addition, the multiple effects of TNF/cachectin (13), which include lipoprotein lipase suppression (14), pyrogenic activity (15), and disturbed brain function (16) could account for several of the pathological features of AIDS, including wasting, fevers, and dementia, respectively. Alternatively, a deficient TNF/cachectin response in AIDS might explain host susceptibility to several opportunistic microorganisms, particularly mycobacteria (17-19).

Previous studies have produced a contradictory array of results, including an increased (20), decreased (21), or normal (22) TNF/cachectin or lymphotoxin production by peripheral blood mononuclear cells isolated from HIV-infected individuals. Two studies have found elevated levels of serum TNF/ cachectin in symptomatic HIV infection $(23,24)$, but an additional report found decreased serum TNF/cachectin levels in HIV-infected individuals compared to uninfected controls (25). In order to determine if HIV infection of macrophages alone causes a disturbance in macrophage TNF/cachectin regulation, an assessment of the synthesis and release of this cytokine during in vitro infection is required. We report here that productive and cytopathic infection of monocyte-derived macrophages with a macrophage-tropic HIV-1 strain does not induce detectable TNF/cachectin protein or mRNA production. In addition, infection fails to alter either the kinetics or dose-response of TNF/cachectin production after LPS stimulation, suggesting that HIV infection and replication does not directly alter macrophage TNF/cachectin regulation.

\section{Methods}

Macrophage culture. Macrophages were prepared from blood monocytes isolated by sequential fibronectin and plastic adherence $(26,27)$. Peripheral blood mononuclear cells (PBMCs) were isolated by FicollHypaque centrifugation and incubated for $50 \mathrm{~min}$ in flasks previously coated with $2 \%$ gelatin and autologous plasma as a source of fibronectin (26). The fibronectin-adherent population was removed by incubation in $5 \mathrm{mM} \mathrm{Na}{ }^{+}$EDTA and incubated in 48-well tissue culture plates (Costar, Cambridge, MA) at $4 \times 10^{5} \mathrm{cells} / \mathrm{ml}$ at $37^{\circ} \mathrm{C} / 5 \% \mathrm{CO}_{2}$ in $1 \mathrm{ml}$ of RPMI 1640 (Irvine Scientific, Santa Ana, CA) supplemented with $50 \mu \mathrm{g} / \mathrm{ml}$ gentamicin and $10 \%$ (vol/vol) heat-inactivated autologous or human $\mathrm{AB}$ serum. $5 \mathrm{~d}$ after incubation, the nonadherent cells were removed by washing, leaving a population of cells that were essentially $100 \%$ nonspecific esterase positive and homogeneous for the phenotype of spreading, maturing macrophages. All media and sera were monitored for endotoxin by Limulus lysate assay and by a sensitive assay for monocyte procoagulant activity (28).

$H I V-1$ infection. Virus stocks were obtained by passage of the mac-

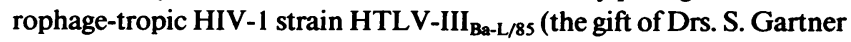
and M. Popovic, National Cancer Institute, Bethesda, MD) (7) in 
monocyte-derived macrophage (MDM) cultures. All virus/MDM cultures were maintained in endotoxin-free conditions without the addition of exogenous growth factors or cytokines. Titration was performed by quadruplicate end-point dilution in MDM cultures, using p24 antigen production (Abbott Laboratories, North Chicago, IL) as the indicator of infection (Table I). For experiments, 5-d MDM cultures containing $\sim 2 \times 10^{5}$ cells per well were infected in 48-well plates by the addition of $\geq 6 \times 10^{5.0}$ macrophage tissue culture infectious doses $\left(\right.$ TCID $_{50}$ ), producing a multiplicity of infection of $\sim 3$. After $2 \mathrm{~h}$ of incubation at $37^{\circ} \mathrm{C}$, the virus inoculum was removed by four washes with serum-free medium and replaced with fresh medium containing $10 \%$ (vol/vol) human AB serum.

LPS stimulation. $6 \mathrm{~d}$ after infection, MDM cultures were stimulated with LPS (Escherichia coli 0111:B4; Calbiochem-Behring, La Jolla, CA) at concentrations ranging from $10 \mathrm{pg} / \mathrm{ml}$ to $100 \mathrm{ng} / \mathrm{ml}$ in duplicate wells. $100-\mu \mathrm{l}$ samples were taken from each well at the indicated time points after stimulation and stored at $-70^{\circ} \mathrm{C}$ before TNF/ cachectin assays.

$T N F /$ cachectin bioassay. Culture supernatants were assayed for TNF/cachectin in a cytotoxicity assay using L929 cells pretreated with $0.5 \mu \mathrm{g} / \mathrm{ml}$ mitomycin $\mathrm{C}$ in 96-well microtiter plates. Recombinan human TNF-alpha $\left(2.51 \times 10^{7} \mathrm{U} / \mu \mathrm{g}\right.$; Genentech, South San Francisco, CA) was assayed in triplicate dilutions to establish a standard curve. $48 \mathrm{~h}$ after incubation, plates were fixed in 5\% formaldehyde in saline and stained with crystal violet before quantitation of cytotoxicity with an automated micro-ELISA reader. Results are expressed as $\mathrm{TNF} /$ cachectin $\mathrm{U} / \mathrm{ml}$. This cytotoxicity assay has a threshold of detection of between 0.1 and $1 \mathrm{U} / \mathrm{ml}$ of recombinant human TNF- $\alpha$.

$T N F /$ cachectin $m R N A$. Macrophage cultures were infected in 48well plates at a multiplicity of infection (m.o.i.) $=3$ as described above. Total cellular RNA was isolated at various times after infection using a modification of the single-step acid guanidinium thiocyanate-phenolchloroform procedure (29) (RNAzol ${ }^{\mathrm{TM}}$; Cinna/Biotecx, Friendswood, TX), followed by chloroform extraction, isopropanol precipitation, and resuspension of total cellular RNA in $1 \mathrm{mM}$ Tris, $\mathrm{pH}$ 7.5. An initial round of reverse transcription (MMLV-Reverse transcriptase; Bethesda Research Laboratories, Gaithersburg, MD) provided cDNA targets for subsequent $\mathbf{4 0}$ cycle PCR amplification. Polymerase chain reaction (PCR) amplification (30-32) was performed using primer pairs (Genetic Designs, Inc., Houston, TX) chosen to target TNF/cachectin exons spanning three separate intron regions (sense: 5 'GGGAATTCATGAGCACTGAAAGCATGATC-3'; antisense: 5'GGAAGCTTTCACAGGGCAATGATCCCAAAGTAGACCTGCCC-3' beginning at positions 152 and 854, respectively, in the CDNA

Table I. Establishment of High Multiplicity, Productive Infection of Macrophages by HIV-I

\begin{tabular}{lccc}
\hline & $\begin{array}{c}\text { HTLV-III } \\
\text { virus stocks }\end{array}$ & $\begin{array}{c}\text { Infected } \\
\text { cultures }\end{array}$ & $\begin{array}{c}\text { Uninfected } \\
\text { cultures }\end{array}$ \\
\hline $\begin{array}{c}\mathrm{p} 24 \text { antigen } \\
(\mathrm{pg} / \mathrm{ml}) \\
\text { Virus infectivity } \\
\left(T C I D_{50} / \mathrm{ml}\right)\end{array}$ & $10^{6.0}$ & $>10^{3}$ & 0 \\
$\begin{array}{c}\text { Cytopathology } \\
(\text { MNGCs })\end{array}$ & $10^{6.0}$ & $10^{3.5}$ & 0 \\
\hline
\end{tabular}

The virus stock was assayed for p24 antigen and titered by end-point dilution in MDM culture in order to establish a defined multiplicity of infection (m.o.i. $=3$ ). For each experiment, supernatants from duplicate wells were tested for p24 antigen and end-point dilution $6 \mathrm{~d}$ after infection. Multinucleated giant cells (MNGC) containing $\geq 5$ nuclei/syncytium were present at least once per high-power field $(\times 400)$ in infected MDM cultures at $6 \mathrm{~d}$ postinfection, but were completely absent in uninfected cultures. sequence of TNF/cachectin (33), and containing additional 8-bp restriction sites at each $5^{\prime}$ end). The product resulting from the amplification of spliced TNF/cachectin mRNA was predicted to be $702 \mathrm{bp}$. The same primer pair used for PCR amplification was used for reverse transcription so that cDNAs were made only from TNF/cachectin-specific targets. Amplification conditions included primer annealing at $37^{\circ} \mathrm{C}$ for $2 \mathrm{~min}$, primer extension at $72^{\circ} \mathrm{C}$ for $10 \mathrm{~min}$, and denaturation at $94^{\circ} \mathrm{C}$ for $90 \mathrm{~s}$ in an automated thermal cycler using a thermostabile DNA polymerase (Thermus aquaticus) supplied by the manufacturer (Perkin Elmer-Cetus, Emeryville, CA). PCR products were visualized on $2 \%$ agarose/ethidium bromide gels, and the identity of amplification products was further confirmed by cleavage at an internal diagnostic restriction site (Hinc II), producing restriction fragments of 502 and $200 \mathrm{bp}$. The sensitivity of this technique was determined by amplifying serially diluted soluble RNA extracts from an LPS-stimulated culture of known cell number $(10 \mu \mathrm{g} / \mathrm{ml} \mathrm{LPS} \times 4 \mathrm{~h}$ in a culture of $10^{5}$ cells), revealing a threshold of detection in terms of cell-equivalents of TNF/cachectin mRNA from a fully activated macrophage culture.

\section{Results}

Establishment of productive and cytopathic infection of MDMs by $H I V-1$. Multinucleated giant cells formed within $72 \mathrm{~h}$ of a high multiplicity infection with HTLV-III ${ }_{\mathrm{Ba}-\mathrm{L} / 85}$, but this cytopathology did not accelerate cell death over an observation period of $21 \mathrm{~d}$ when compared with uninfected cultures, as determined by adherent cell counts (data not shown). Approximately $20-40 \%$ of the cell nuclei in infected wells was incorporated into multinucleated giant cells (Fig. 1). We have shown previously by electron microscopy that these syncytia contain abundant HIV virions within intracellular vesicles and on the plasma membrane (27). The production of p24 antigen and infectious virus indicated that significant viral replication was occurring in HIV-infected wells (Table I).

$T N F /$ cachectin release is not induced by $H T L V-I I I_{B a-L / 85}$ infection. MDM culture supernatants were tested for the presence of TNF/cachectin before, immediately after, and several days after infection with HIV-1. In an assay with a threshold of detection of $0.1 \mathrm{U} / \mathrm{ml}$ of recombinant human TNF, spontaneous TNF/cachectin production was not detected in either infected or uninfected cultures before LPS stimulation (Table II). This result was consistent with the demonstration that TNF/cachectin production is an inducible and not a constitutive event in MDM cultures which exclude endotoxin contamination (28). When the same cultures were stimulated with 100 $\mathrm{ng} / \mathrm{ml}$ LPS $5 \mathrm{~d}$ after infection, comparable TNF/cachectin responses occurred in both infected and uninfected cultures (Table II).

Dose-response and kinetic curves following LPS stimulation are not altered by HTLV-III $I_{B a-L / 85}$ infection. To define the responsiveness of infected cells to LPS stimulation further, dose-response and kinetic experiments were performed $6 \mathrm{~d}$ after HIV infection when cytopathic effects and viral replication were well established. The dose-response curves generated for TNF/cachectin were produced by LPS concentrations ranging from $10 \mathrm{pg} / \mathrm{ml}$ to $100 \mathrm{ng} / \mathrm{ml}$. To assess the kinetics of TNF/cachectin release, supernatants were collected at six different time points after stimulation (Fig. 2). In four separate experiments, the minimal LPS dose required to induce detectable TNF/cachectin production varied between 10 and 100 $\mathrm{pg} / \mathrm{ml}$. Maximal TNF/cachectin production was seen at $6 \mathrm{~h}$ after LPS stimulation, with a return to nearly undetectable levels by $96 \mathrm{~h}$. HTLV-III $\mathrm{Ba}_{\mathrm{B}-\mathrm{L} / 85}$ infection failed to alter either 


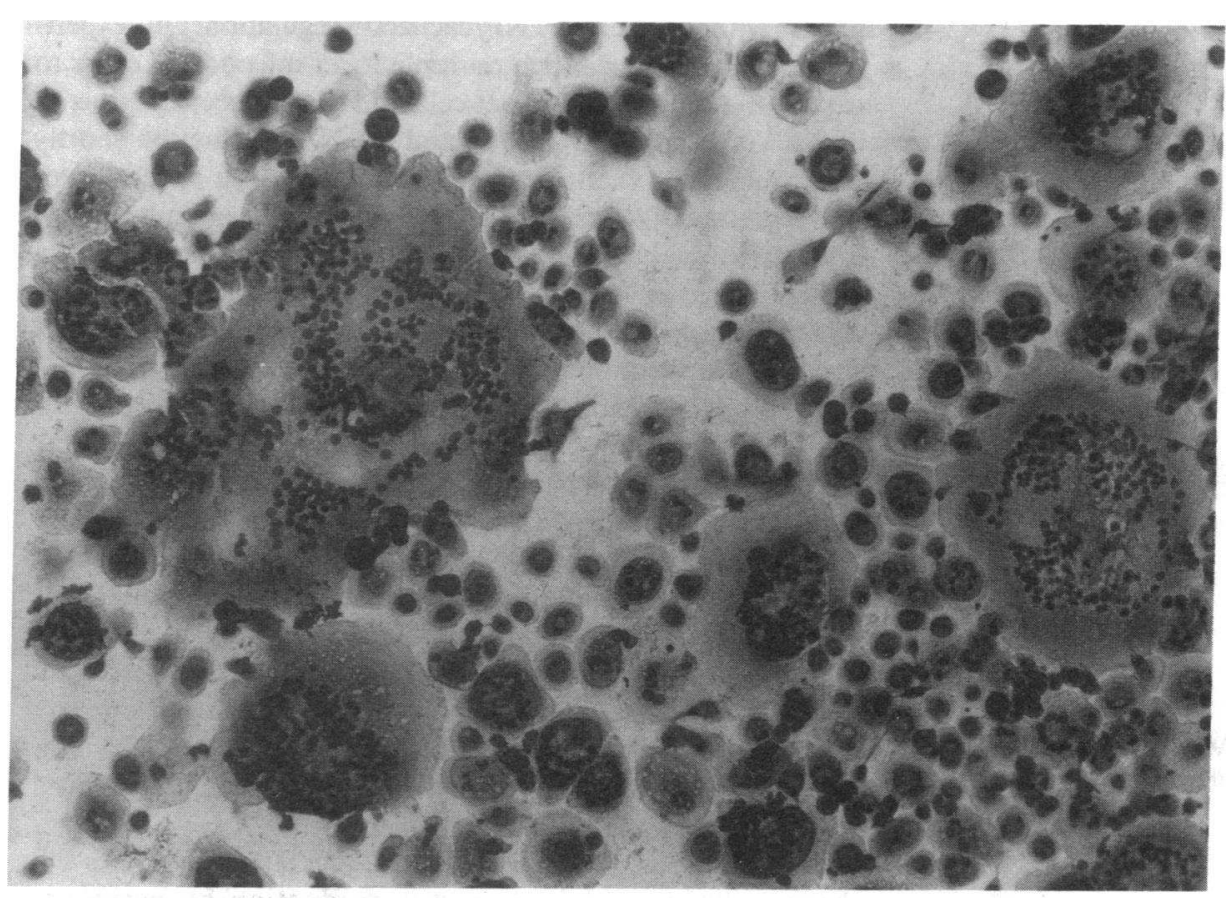

Figure 1. Multinucleated giant cells from a culture of HIV-infected macrophages. Primary monocyte-derived macrophages (MDM) were incubated on coverslips for $5 \mathrm{~d}$ before infection with HTLV-III $\mathrm{Ba-L/85.} 4 \mathrm{~d}$ after infection, coverslips were removed from tissue culture plates, fixed in methanol, and Wright-stained in order to demonstrate nuclei within macrophage syncytia. the dose-response or the kinetics of TNF/cachectin production in these LPS-stimulated macrophage cultures.

$H T L V-I I I_{B a-L / 85}$ infection does not induce macrophage $T N F /$ cachectin $m R N A$ production in unstimulated cultures or alter TNF/cachectin MRNA production in LPS-stimulated cultures. TNF/cachectin-specific mRNA was assayed following HIV infection using reverse transcription and PCR amplification (Fig. $3 \mathrm{~A}$ ). In unstimulated cultures, no amplification products were present in either infected or uninfected cultures. After LPS stimulation, both infected and uninfected cultures yielded the predicted 702 b.p. amplification product from TNF/cachectin mRNA. Amplified TNF/cachectin mRNA from serial dilutions of an LPS-stimulated culture demon-

Table II. Baseline TNF/Cachectin Production in HIV-1 Infected and Uninfected Macrophage Cultures

\begin{tabular}{cccc}
\hline & & \multicolumn{2}{c}{ TNF/Cachectin $(\mathrm{U} / \mathrm{ml})$} \\
\cline { 3 - 4 } Time postinfection & LPS $(100 \mathrm{ng} / \mathrm{ml})$ & Uninfected & Infected \\
\hline \multirow{2}{*}{$0 \mathrm{~h}$} & - & $<0.1$ & $<0.1$ \\
$6 \mathrm{~h}$ & - & $<0.1$ & $<0.1$ \\
$1 \mathrm{~d}$ & - & $<0.1$ & $<0.1$ \\
$3 \mathrm{~d}$ & - & $<0.1$ & $<0.1$ \\
$5 \mathrm{~d}$ & - & $<0.1$ & $<0.1$ \\
$5 \mathrm{~d}$ & + & $45.7 \pm 11.8$ & $33.2 \pm 11.9$
\end{tabular}

5-d old MDM cultures were infected with HTLV-III ${ }_{\mathrm{Ba}-\mathrm{L} / 85}$ at a m.o.i. $=3$. At the indicated times following infection, supernatants were harvested for TNF/cachectin determinations by L929 cytotoxicity assay. On day 5 , cultures were stimulated with $100 \mathrm{ng} / \mathrm{ml}$ LPS and assayed for TNF/cachectin release $6 \mathrm{~h}$ later in order to demonstrate that both infected and uninfected cultures were responsive to LPS stimulation. The apparent difference between infected and uninfected cultures after stimulation was not a consistent finding between experiments. Values are reported as mean TNF/cachectin $(\mathrm{U} / \mathrm{ml}) \pm \mathrm{SD}$ of four cultures. strated that the detection threshold in these studies was less than a $10^{-4}$ dilution of a culture containing $10^{5}$ cells, or between 1 and 10 cell-equivalents of TNF/cachectin mRNA from a fully activated macrophage culture (Fig. $3 B$ ). Restriction endonuclease digestion with Hinc II (Fig. $3 C$ ) yielded the expected restriction fragments of the positive samples from Fig. $3 \mathrm{~A}$, which are diagnostic for the TNF/cachectin-specific identity of the amplified products. Actin RNA amplification
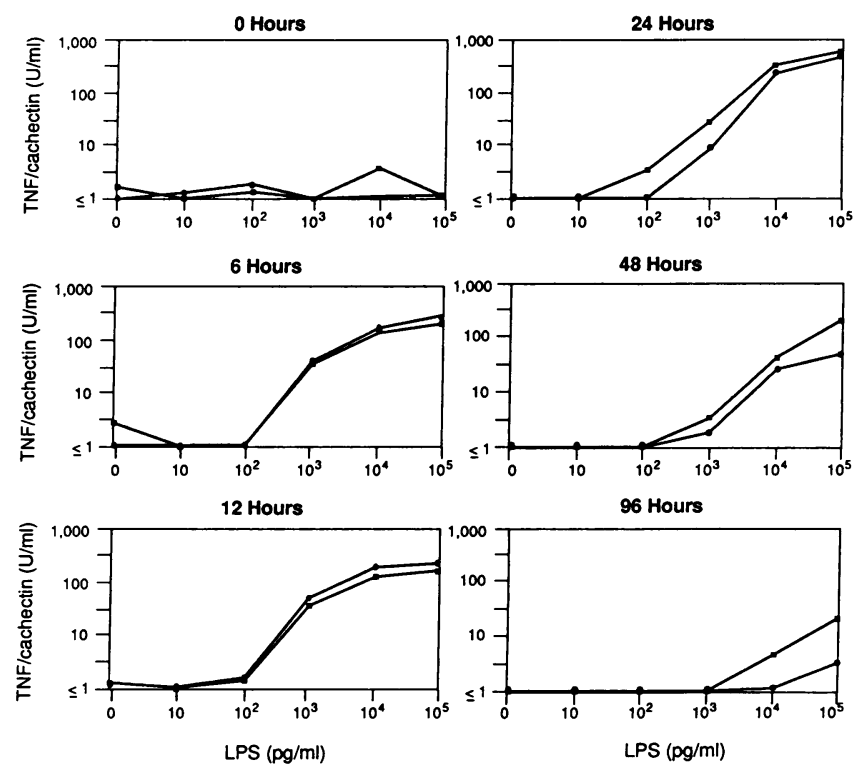

Figure 2. Dose-response curves of TNF/cachectin production after LPS stimulation. Supernatants from HIV-1 infected (- - ) and uninfected (- - wells were harvested and assayed for TNF/cachectin activity at six different time-points after LPS stimulation. Data points represent means of duplicate wells graphed on a log-log plot. In the experiment shown, the threshold of detection of TNF/cachectin was $1 \mathrm{U} / \mathrm{ml}$. No statistically significant difference occurred at any time point with any dose of LPS in four separate experiments. 


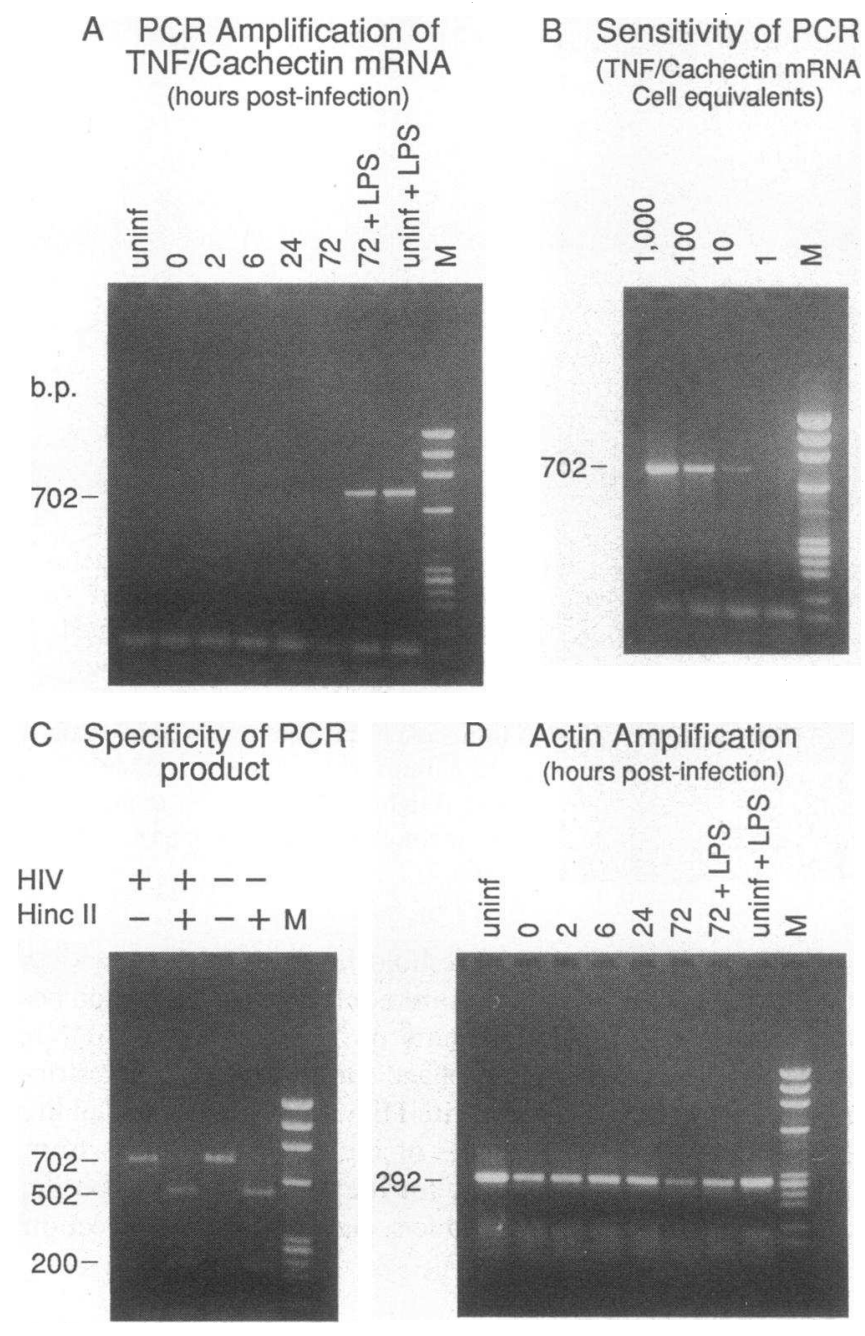

Figure 3. PCR analysis of TNF/cachectin-specific RNA in infected and uninfected cultures. $(A)$ 5-d-old macrophage cultures infected at high multiplicity were lysed and total cellular RNA was extracted and reverse transcribed before 40 cycles of PCR amplification. No TNF/cachectin-specific mRNA was detectable at any time in unstimulated cultures, whether or not they were infected with HIV-1. Comparable TNF/cachectin mRNA amplification products (702 bp) were readily detectable in both uninfected and 72-h infected cultures stimulated with $10 \mu \mathrm{g} / \mathrm{ml}$ LPS. (B) Sensitivity of the PCR amplification technique was determined by serial dilution of RNA from an LPSstimulated culture containing $10^{5}$ macrophages. TNF/cachectin mRNA was detectable at $10^{-4}$ but not at $10^{-5}$ dilution of the original RNA, demonstrating a sensitivity to between 1 and 10 cell-equivalents of TNF/cachectin mRNA from a fully activated culture. $(C)$ Hinc II digest of 72-h infected and uninfected amplification products from LPS-stimulated cultures. The diagnostic restriction fragments ( 502 and $200 \mathrm{bp}$ ) confirm the identity of the $702 \mathrm{bp}$ amplification product as TNF/cachectin-specific. (D) Actin RNA amplification from all samples used in A yielded the predicted 292 bp product. $M$; marker lane with Phi-X174/Hae III molecular weight standards.

was performed (Fig. $3 \mathrm{D}$ ) to confirm the presence of cellular RNA and the efficiency of PCR amplification for all samples.

\section{Discussion}

The data presented here demonstrate that HTLV-III ${ }_{\mathrm{Ba}-\mathrm{L} / 85}$ can establish a productive and cytopathic infection in macro- phages without altering TNF/cachectin regulation. Our experimental system used a high multiplicity of infection in order to expose the majority of target cells to HIV. This enabled us to assess TNF/cachectin protein and mRNA production shortly after infection, when viral replication was both synchronous and widespread in the culture system, as well as several days after infection when the cytopathic effects were most prominent. Endotoxin contamination was minimized since it may affect HIV replication (27) and since endotoxin induces TNF/ cachectin production in MDMs even at minute concentrations (28). No TNF/cachectin was released from unstimulated MDMs, whether or not they were infected with HIV. Similarly, cultured macrophages, whether or not they were infected with HIV, contained no detectable TNF/cachectin mRNA. This determination was made by a PCR amplification technique sensitive enough to detect $<10$ cell-equivalents of TNF/cachectin mRNA from a fully activated macrophage culture. LPS concentrations as low as $10-100 \mathrm{pg} / \mathrm{ml}$ could elicit TNF/cachectin production in our culture system, and the resulting kinetic and dose-response curves from LPS stimulation were indistinguishable between infected and uninfected cultures.

Contradictory results have been generated by studies that have examined TNF/cachectin production by peripheral blood mononuclear cells from individuals infected with HIV. A deficient response to PHA/PMA stimulation (21), an unimpaired tumoricidal response to LPS stimulation (22), and increased baseline and interferon- $\gamma$ stimulated cytolytic activity and TNF/cachectin secretion (20) have all been reported. Two reports demonstrated a correlation between serum TNF/cachectin levels and clinical disease in HIV-infected individuals $(23,24)$, but other studies have found either no measurable serum TNF/cachectin in patients with AIDS-related-complex or $\operatorname{AIDS}(21,34)$ or decreased levels when compared to uninfected controls (25). An additional confounding factor in the interpretation of these studies is that they do not discriminate between a direct effect of HIV infection or in vivo macrophage activation by other factors such as coexisting infections or immune responses (35).

The variety of results obtained with cells from HIV-infected individuals underscores the need to study macrophages that are infected in vitro in order to address the putative direct role of HIV in TNF/cachectin dysregulation. This study took advantage of conditions of infection in vitro that yielded high levels of viral replication and pronounced cytopathology. Such a system should unmask any ability of HIV to alter TNF/cachectin regulation, whether that ability derives from the physical properties of the virus binding to cell receptors, or from intracellular mechanisms responding to viral replication. We tested for the possibility of virion-cell receptor interactions by exposing target MDMs to a defined, high multiplicity input of virus prepared in endotoxin-free conditions. No measurable $\mathrm{TNF} /$ cachectin response followed exposure to virus, suggesting that no virion-receptor interactions occurred that were capable of "activating" MDMs. Additionally, the possibility of a macrophage response to viral infection and replication was tested for during active, high level HIV replication. The LPS dose-response and kinetic data demonstrated that viral replication occurred without inducing either TNF/cachectin activity or mRNA in unstimulated cultures and without interfering with the stimulation by LPS of TNF/cachectin activity or mRNA. 
The possibility exists that the failure of $\mathrm{HTLV}-\mathrm{III}_{\mathrm{Ba}-\mathrm{L} / 85}$ to induce potentially pathogenic TNF/cachectin dysregulation is a strain-specific rather than a general characteristic of HIV or that isolation of MDMs by fibronectin adherence selects against a subset of cells particularly responsible for production of this cytokine by HIV infection. In contrast to most other HIV-1 strains, however, HTLV-III $\mathrm{Ba}_{\mathrm{L} / 85}$ replicates to high titers in MDMs without the addition of exogenous cytokines or growth factors. In addition, it produces cytopathology in vitro that is similar to the multinucleated giant cells observed in patients with AIDS at autopsy. These characteristics make HTLV-III ${ }_{\mathrm{Ba}-\mathrm{L} / 85}$ a suitable prototypic strain for the in vitro demonstration of any putative TNF/cachectin dysregulation that may accompany in vivo HIV infection. The failure of HTLV-III $_{\mathrm{Ba}-\mathrm{L} / 85}$ to alter the production by macrophages of TNF/cachectin transcripts or protein establishes that the constitutive mechanisms of HIV infection and replication operate independently of macrophage TNF/cachectin regulation. If, in fact, TNF/cachectin plays a role in the pathogenesis of infection by HIV, it may be necessary to consider its elaboration by cells other than macrophages or its induction in macrophages as a result of factors other than direct HIV infection.

\section{Acknowledgments}

We gratefully acknowledge the expert technical assistance of Philip Oh, Sara Albanil, Caroline Ignacio, Sandra Rasad, and the administrative assistance of Sharon Wilcox.

This work was supported by grants from the National Institutes of Health (AI-25316, AI-52578, AI-62548, AI-07036, HB-67019), and by the Veterans Administration.

Note added in proof. Since the submission of our manuscript, two related studies have been published. Molina et al. (36) reported that acutely, but not chronically, infected THP-1 monocytoid cells produced more TNF after stimulation with LPS or LPS plus IFN $\gamma$ than did uninfected cells. Merrill et al. (37), used a different HIV-1 strain and a different macrophage culture system than those reported here and found that TNF production was rapidly induced by exposure to either live or heat-killed virus.

\section{References}

1. Barre-Sinoussi, F., J. C. Chermann, R. Rey, M. T. Nugeyre, S. Chamaret, J. Gruest, C. Dauguet, C. Axler-Blin, F. Vezinet-Brun, C. Rouzioux, W. Rozenbaum, and L. Montagnier. 1983. Isolation of a $\mathrm{T}$-lymphotropic retrovirus from a patient at risk for acquired immune deficiency syndrome (AIDS). Science (Wash. DC). 220:868-871.

2. Gallo, R. C., S. Z. Salahuddin, M. Popovic, G. M. Shearer, M. Kaplan, B. F. Haynes, T. J. Palker, R. Redfield, J. Oleske, B. Safai, G. White, P. Foster, and P. D. Markham. 1984. Frequent detection and isolation of cytopathic retroviruses (HTLV-III) from patients with AIDS and at risk for AIDS. Science (Wash. DC). 224:500-503.

3. Ho, D. D., T. R. Rota, and M. S. Hirsch. 1986. Infection of monocyte/macrophages by human T lymphotropic virus type III. $J$. Clin. Invest. 77:1712-1715.

4. Nicholson, J. K. A., G. D. Cross, C. S. Callaway, and J. S. McDougal. 1986. In vitro infection of human monocytes with human T lymphotropic virus type III/lymphadenopathy-associated virus (HTLV-III/LAV). J. Immunol. 137:323-329.

5. Koyanagi, Y., S. Miles, R. T. Mitsuyasu, J. E. Merrill, H. V. Vinters, and I. S. Chen. 1987. Dual infection of the central nervous system by AIDS viruses with distinct cellular tropisms. Science (Wash. DC). 236:819-822.

6. Salahuddin, S. Z., R. M. Rose, J. E. Groopman, P. D. Markham, and R. C. Gallo. 1986. Human T lymphotropic virus Type III infection of human alveolar macrophages. Blood. 68:281-284.

7. Gartner, S., P. Markovits, D. M. Markovitz, M. H. Kaplan, R. C. Gallo, and M. Popovic. 1986. The role of mononuclear phagocytes in HTLV-III/LAV infection. Science (Wash. DC). 233:215-219.

8. Gartner, S., P. Markovits, D. M. Markovitz, R. F. Betts, and M. Popovic. 1986. Virus isolation from and identification of HTLV-III/ LAV-producing cells in brain tissue from a patient with AIDS. J. Am. Med. Assoc. 256:2365-2371.

9. Gendelman, H. E., J. M. Orenstein, M. A. Martin, C. Ferrua, R. Mitra, T. Phipps, L. A. Wahl, H. C. Lane, A. C. Fauci, D. S. Burke, D. Skillman, and M. S. Meltzer. 1988. Efficient isolation and propagation of human immunodeficiency virus on recombinant colony-stimulating factor 1-treated monocytes. J. Exp. Med. 167:1428-1441.

10. Ho, D. D., R. J. Pomerantz, and J. C. Kaplan. 1987. Pathogenesis of infection with human immunodeficiency virus. $N$. Engl. J. Med. 317:278-286.

11. Beutler, B., N. Krochin, I. W. Milsark, A. Goldberg, and A. Cerami. 1986. Induction of cachectin (tumor necrosis factor) synthesis by influenza virus: deficient production by endotoxin-resistant $(\mathrm{C} 3 \mathrm{H} /$ HEJ) macrophages. Clin. Res. 34:491a. (Abstr.)

12. Aderka, D., H. Holtmann, L. Toker, T. Hahn, and D. Wallach. 1986. Tumor necrosis factor induction by Sendai virus. J. Immunol. 136:2938-2942.

13. Beutler, B., and A. Cerami. 1989. The biology of cachectin/ TNF- a primary mediator of the host response. Annu. Rev. Immunol. 7:625-655.

14. Beutler, B., J. Mahoney, N. Le Trang, P. Pekala, and A. Cerami. 1985. Purification of cachectin, a lipoprotein lipase-suppressing hormone secreted by endotoxin-induced RAW 264.7 cells. J. Exp. Med. 161:984-995.

15. Dinarello, C. A., J. G. Cannon, S. M. Wolff, H. A. Bernheim, B. Beutler, A. Cerami, I. S. Figari, M. A. Palladino, and J. V. O'Connor. 1986. Tumor necrosis factor (cachectin) is an endogenous pyrogen and induces production of interleukin 1. J. Exp. Med. 163:1433-1450.

16. Kreuger, J. M., S. Shoham, D. Davenne. 1986. Immune modulators as promoters of slow wave sleep. Clin. Neuropharmacol. 9(Suppl. 4):462.

17. Kindler, V., A. Sappino, G. E. Grau, P. Piguet, and P. Vassalli. 1989. The inducing role of tumor necrosis factor in the development of bactericidal granulomas during BCG infection. Cell. 56:731-740.

18. Bermudez, L. E. M., and L. S. Young. 1988. Tumor necrosis factor, alone or in combination with IL-2, but not IFN-gamma, is associated with macrophage killing of Mycobacterium avium complex. J. Immunol. 140:3006-3013.

19. Schnittman, S., H. C. Lane, F. G. Witebsky, L. L. Gosey, M. D. Hoggan, and A. Fauci. 1988. Host defense against Mycobacteriumavium complex. J. Clin. Immunol. 8:234-243.

20. Wright, S. C., A. Jewett, R. Mitsuyasu, and B. Bonavida. 1988. Spontaneous cytotoxicity and tumor necrosis factor production by peripheral blood monocytes from AIDS patients. J. Immunol. 141:99-104.

21. Ammann, A. J., M. A. Palladino, P. Volberding, D. Abrams, N. L. Martin, and M. Conant. 1987. Tumor necrosis factors alpha and beta in acquired immunodeficiency syndrome (AIDS) and AIDS-related complex. J. Clin. Immunol. 7:481-485.

22. Haas, J. G., G. Riethmuller, and H. W. L. Ziegler-Heitbrock. 1987. Monocyte phenotype and function in patients with the acquired immunodeficiency syndrome (AIDS) and AIDS-related disorders. Scand. J. Immunol. 26:371-379.

23. Lahdevirta, J., C. P. J. Maury, A. Teppo, and H. Repo. 1988. Elevated levels of circulating cachectin/tumor necrosis factor in patients with acquired immunodeficiency syndrome. Am. J. Med. 85:289-291.

24. Reddy, M. M., S. J. Sorrell, M. Lange, and M. H. Grieco. 1988. Tumor necrosis factor and HIV p24 antigen levels in serum of HIVinfected populations. Journal of Acquired Immune Deficiency Syndromes. 1:436-440. 
25. Holland, S. M., R. L. Colebunders, H. L. Francis, Khondi, Kapita, and T. C. Quinn. 1989. Tumor necrosis factor (TNF) in the plasma of Africans infected with HIV. V. Intl. AIDS Conf. Montreal, Canada. Th.B.O.30.

26. Freundlich, B., and N. Avdalovic. 1983. Use of gelatin/plasma coated flasks for isolating human peripheral blood monocytes. J. Immunol. Methods. 62:31-37.

27. Kornbluth, R. S., P. S. Oh, J. R. Munis, P. H. Cleveland, and D. D. Richman. 1989. Interferons and bacterial lipopolysaccharide protect macrophages from productive infection by human immunodeficiency virus in vitro. J. Exp. Med. 169:1137-1151.

28. Kornbluth, R. S., and T. S. Edgington. 1986. Tumor necrosis factor production by human monocytes is a regulated event: induction of TNF-alpha-mediated cellular cytotoxicity by endotoxin. J. Immunol. 137:2585-2591.

29. Chomczynski, P., and N. Saachi. 1987. Single-step method of RNA isolation by acid guanidinium thiocyanate-phenol-chloroform extraction. Anal. Biochem. 162:156-159.

30. Saiki, R. K., S. Scharf, F. Faloona, K. B. Mullis, G. T. Horn, H. A. Erlich, and N. Arnheim. 1985. Enzymatic amplification of betaglobin genomic sequences and restriction site analysis for diagnosis of sickle cell anemia. Science (Wash. DC). 230:1350-1354.

31. Saiki, R. K., D. H. Gelfand, S. Stoffel, S. J. Scharf, R. Higuchi, G. T. Horn, K. B. Mullis, and H. A. Erlich. 1988. Primer-directed enzymatic amplification of DNA with a thermostable DNA polymerase. Science (Wash. DC). 239:487-491.

32. Rappolee, D. A., A. Wang, D. Mark, and Z. Werb. 1989. Novel method for studying mRNA phenotypes in single or small numbers of cells. J. Cell. Biochem. 39:1-11.

33. Pennica, D., G. E. Nedwin, J. S. Hayflick, P. H. Seeburg, R. Derynck, M. A. Palladino, W. J. Kohr, B. B. Aggarwal, and D. V. Goeddel. 1984. Human tumor necrosis factor: precursor structure, expression and homology to lymphotoxin. Nature (Lond.). 7 312:724-728.

34. Peterson, E., Y. L. Wang, R. E. Schwartz, M. Ho, and T. L. Whiteside. 1989. Tumor necrosis factor-alpha in patients with HIV infection. FASEB (Fed. Am. Soc. Exp. Biol.) J. 3:A1281. (Abstr.)

35. Kornbluth, R. S., S. A. Gregory, and T. S. Edgington. 1988. Initial characterization of a lymphokine pathway for the immunologic induction of tumor necrosis factor-alpha release from human peripheral blood mononuclear cells. J. Immunol. 141:2006-2015.

36. Molina, J. M., D. T. Scadden, R. Byrn, C. A. Dinarello, and J. E. Groopman. 1989. Production of tumor necrosis factor alpha and interleukin 1 beta by monocytic cells infected with human immunodeficiency virus. J. Clin. Invest. 84:733-737.

37. Merrill, J. E., Y. Koyanagi, and I. S. Y. Chen. 1989. Interleukin-1 and tumor necrosis factor alpha can be induced from mononuclear phagocytes by human immunodeficiency virus type 1 binding to the CD4 receptor. J. Virol. 63:4404-4408. 